The Pioneers Get Shot: Music Video, Independent Production and Cultural Hierarchy in Britain.

\title{
Emily Caston
}

\section{University of West London}

\begin{abstract}
This article identifies and summarises the main findings of the AHRC research project Fifty Years of British Music Video, 1966-2016. It contextualises the history of music video as a film practice within an unspoken cultural hierarchy of screen arts widely shared in universities, policy circles and the British Film Institute. The article documents the main stages in the development of the music video industry, and highlights the extent to which the pioneers served as early adopters of new technologies in videotape, telecine and digital filmmaking. The ACTT consistently lobbied against music video producers, as did the Musicians' Union. Between the ACTT, the MU and the BBC, music video producers emerged from the 1980s with virtually no protections of their rights. The ACTT's issue was new video technology which it opposed. It opposed offline editing on video tape because it would lead to redundancies of film editors and potentially required fewer post crew. The MU's issue was royalty payments to session musicians and lip synch. The music video industry has functioned as a crucial R\&D sector and incubator for new talent and new technologies in the British film and television industries as a whole, without experiencing any of the financial rewards, cultural status or copyright protections of the more esteemed 'screen arts'.
\end{abstract}

Key Words: Screen industries, Music video, Telecine, ACTT, R\&D creative industries, Post production, British film policy, British film industry, Videotape, British television, Production Studies 


\section{Introduction}

One of the questions raised by our research project was explaining the relationship between the music video production sector and the broader film and television industry in Britain. That question could only be answered by undertaking a much larger task of mapping the British screen industries which lies beyond the scope of this article but is a necessary task for scholars and politicians interested in creating a fertile legal, educational and economic agriculture for the next generation. Here I present my own research into that relationship in the context of theoretical and policy issues raised by John Hill. The analysis touches on key debates about the 'cultural value' of film in Government policy (Hill 2004), the Government's 'Industrial Strategy', and Britain's creative economy and the skills and education agenda (e.g. Work Foundation 2007; Bakhshi, Hargreaves and Mateos-Garcia 2013; Bakhshi and Windsor 2015; Bazalgette 2017).

To date, academic attention has tended to focus not on actual industrial relations between music video producers and the rest of the screen industries but on a (rather limited) set of perceived aesthetic effects inflicted on the latter by the former (see especially Vernallis 2008 and Dickinson 2003). Exceptions to this pattern include Kevin Donnelly whose more comprehensive, historical analysis locates music video within the British artists' film and video tradition (2007). Twenty years earlier, E. Anne Kaplan pointed out the affinity of music videos with earlier avant-garde cultural formations (1987). John Richardson (2011: 58) locates music video within a surrealist aesthetic that pre-dated MTV and, particularly in his analysis of The Gorillaz at the Brit Awards, makes an important contribution towards an understanding of music video within British film culture (2011: 201-239). Will Fowler (2017) extends and deepens this analysis of the connections with artists' moving image work in the early 1980s.

But these works are the exception rather than the rule. Part of the reason for this limited approach is that music videos have been treated as an inferior social/political/economic entity to feature films. Underlying this is, I believe, a tendency to place music video low down within a cultural hierarchy of film content. As David Mallet, acclaimed director of most of David Bowie's videos 
through the 1980 s, attests, 'Music video was a medium that was not regarded at all. It was like lavatory paper. In England they were referred to as "fillers". That was an insult.' (Tannebaum and Marks 2012: 7). Figure 1 illustrates the cultural hierarchy:

\section{INSERT Figure 1}

The diagram represents a cultural hierarchy of screen production. The concept of this hierarchy is taken from Bourdieu's work. For Bourdieu, not all modes of cultural expression are accorded equal 'dignity and value' in a given society but are organized according to a hierarchy independent of individual opinions, which defines cultural legitimacy and its gradations.' (Bourdieu 1990: 95, cited in Hill 2004: 30). Music video sits at the base largely as a consequence of the movement to 'legitimise' cinema films as a middle-class art which dates back to the 1920s when cinema was largely a working-class form of entertainment rooted in the music hall. It found its T.S. Eliot in the form of Stephen Heath and Colin McCabe who at Cambridge in the 1970s led the cavalry in the march to found 'film studies' in the humanities alongside literary studies. The impact of this movement on UK film policy and the British Film Institute has been analysed by John Hill (2004).

I want not only to question this hierarchy but also present data from our research project to demonstrate that it is based on an ill-conceived notion that music video is a physically separate part of the economy from feature film production. Our research project shows that music video is part of an integrated screen production sector in Britain within a larger network described as the 'screen industries'. This is a term used by the BFI in recent publications to describe a coherent segment of British industry involved in moving image production, reception and distribution. Clear definition has remained elusive however, and is not evident from the BFI's own publications (Olsberg with Nordacity 2015; Cambridge Econometrics 2005; Oxera 2017; Carey et al for the Work Foundation 2017). Yet it is almost impossible to narrate the history of the moving image without this concept. 
In order to pursue this argument, I will do four things. First, I want to present a definition of the 'screen production sector' in Britain within which music video sits as an integrated activity alongside film and television. Second, I will give an outline history of the political and economic struggle through which music video production emerged as a new industry. Thirdly I want to identify and explain some of the crucial R\&D (Research and Development) functions music video has fulfilled. Like User-Generated Content on YouTube today, for decades music video was able to attract and retain visually innovative young people from diverse backgrounds to an extent that has not been achieved in film and television production. Finally, I will return to the cultural hierarchy of screen industries in relation to the need, highlighted by the current Government's industrial strategy, for well-funded and innovative R\&D sectors in all creative industries.

\section{The 'Hidden Screen Industries'}

Figure 2 demonstrates the extent to which the screen production sector supplies content to a variety of industries and consumers. By 'production screen industries' I mean the companies, activities and people involved in the production of content for the screen industries such as feature films. The production sectors have attracted considerable attention recently as a result of the new 'production studies' paradigm initiated by John Caldwell (2008). As far as I'm aware there has been no study of the integrated structural relationship between different industries within this sector.

\section{INSERT Figure 2}

Broadly, through most of the twentieth century, industries represented by the coloured rectangles have commissioned and financed the production sector to produce content for a number of viewing platforms or media - from the music hall to the cinema, to television, mobile and computers. The oval shape underneath represents the production base of production companies, 
agents and diary services, post-production, VFX, and audio production houses that have evolved. Music video is a specific social and economic network with its own culture of production and supply chain; it sits within this production base where it is horizontally integrated with the feature films, television, and commercials supply chain / network / culture of productions. At certain points in history the production facilities for all of these supply chains have been owned and managed inhouse, especially by the larger corporations. Some sections of the British production base have received considerable attention such as independent television production, feature film production, and individual film production companies. Music video, like 'industrial' film, ${ }^{1}$ is one that has received very little attention. With the exception of the landmark (Hill and McLoone 1996) and a number of recent works on film and television (Percival and Hesmondhalgh 2014), the connections between each have received little to none

Elsewhere (Caston and Smith 2017), I referred to the music video industry as a 'hidden screen industry'. The concept also covers advertising, fashion, and the corporate industries. They too are obscured by the formal representations of the BFI and most policy documents and reports produced on the screen industries. They sit at the base of the cultural hierarchy of screen arts in Britain. But they are part of a complex ecosystem which forms part of the larger 'screen industries'. Parts of these industries have been termed inaccurately 'the promotional screen industries' by Helen Powell (2013) and Paul Grainge and Catherine Johnson (2015). Likewise, the concept of 'interstitials' deployed by John Ellis (2011) not only obscures the sui generis cultural and economic value of these moving image works but falls prey to the ideological framework of the cultural hierarchy of screen industries.

\section{The British Music Video Industry}

As Smith's article in this dossier shows, from the mid-1960s music videos were produced on an ad hoc basis. The practice was instigated by a small number of visionaries and pioneers who embraced the artistic potential of film sometimes without the support of record labels. The challenge for any band wanting to make a promotional film was 'how do I get my hands on a camera, lights and editing 
equipment?' There were no independent production companies, and no film equipment suppliers were prepared to hire equipment to non-unionised individuals. Unlike today, 'professional' film equipment was extremely expensive. In order to shoot his idea for 'Dead End Street' (1966), Ray Davies hired an ITV news crew complete with a camera kit. ${ }^{2}$ Peter Whitehead was only able to direct his landmark videos for Eric Burdon and the Animals and The Rolling Stones because he'd purchased a $16 \mathrm{~mm}$ camera and owned a Steenbeck. ${ }^{3}$

Directors had faced exactly the same problems one decade earlier when trying to shoot commercials for independent television after 1955. For James Garrett, there was an 'escapable reality which quite profoundly affected the coming into being of a commercial production business, and that was the antagonism towards television in general and commercials in particular which prevailed in the "establishment" film industry.' (1986: 388). Garrett's observation is crucial to understanding the complex economic structure and power relations of the screen industries since the late 1950s:

Everyone concerned with the so-called legitimate feature-film world regarded this upstart new service - quite rightly as it transpires - as a very real threat to their already ailing cinema-entertainment business. ... Studios, laboratories, equipment, people were, for the most part, financially, emotionally or morally, owned by, and committed to, a world that rejected commercial television and all its works. (1986: 388-9).

The same situation prevailed for music videos in the 1970s. The difficulty that faced Britain's first generation of music video producers and directors was that independent television production was a closed shop, controlled by the Association of Cinematograph Television and Allied Technicians (ACTT). No-one could make content for television unless they were a member of the ACTT, but they weren't able to join until they had completed work on a set number of union shoots in a prescribed role. During the late 1950s and 1960s, the ACTT also came to represent the commercials production sector, although what date exactly is not clear. But it deemed that despite 
the fact that the majority of the producers came from documentary, the commercials companies should fall under the 'feature agreement' according to which twelve people must work on a film unit (four each in the production, camera and sound departments), as opposed to documentary which required only four people in total; though illogical, this was effected in order to create greater employment opportunities and security for ACTT members. By the 1980s, 'commercial production' was a specified area recognised and governed by the ACTT (see Fletcher 1983).

Because the ACTT had endorsed TV commercial production, young directors were able to utilise the infrastructure established by these companies. And the commercials managers were willing to turn a blind eye to new music video directors infringing the ACTT commercials agreement of twelve people per film shoot. John Crome took this approach when he made the video for Manfred Mann's 'Mighty Quinn' (1967) through commercials production company Eyeline (owned by Harold Orton, previously a production manager at Ealing Studios). There was no 'production budget' as such: the band's manager Gerry Bron commissioned the video and provided just enough money to buy some $16 \mathrm{~mm}$ film stock and food for the shoot. ${ }^{4}$ It was shot over two days, one main day of principal photography at Osterley Park (for which they paid £50) and another day shooting cutaways without the band across London. Without a union endorsed production company, Crome could not have hired camera or lighting equipment (from Mr Lighting).

Whilst no-one yet could earn an annual living wage from music video, demand for music videos in the UK rose enough in the late 1970s to motivate a number of enthusiastic filmmakers to launch their own dedicated music video production companies. These companies sat outside the union structure. The most significant was set up by Jon Roseman in 1977. According to Roseman's autobiography, the decision to start the company was motivated by the success of Queen's 'Bohemian Rhapsody' (1975). The director, Bruce Gowers had been a friend of Roseman's. Other companies soon emerged in response to rising demand for videos from UK producers. Limelight was founded in 1979 by brother and sister Steve Barron (director) and Siobhan Barron (executive producer) along with producer Adam Whittaker. 
One of the most influential companies, MGMM, was formed by producer Scott Millaney and director Brian Grant initially as MG productions, subsequently becoming MGMM when David Mallet and Russell Mulcahy left Jon Roseman's to join Scott and Brian (in protest against an interview Roseman had given to a national newspaper about the company). Other new companies included GLO Productions (run by Gordon Lewis, and active between 1982 and 1990), which represented Tim Pope who directed most of The Cure's videos as well as Peter Care who directed the acclaimed videos for Cabaret Voltaire's 'Sensoria' and Marc Romanek who was based in LA but was represented by GLO in the UK. Aldabra was a company run by Tim Bevan and Sarah Radclyffe, which represented Bernard Rose who directed UB40's 'Red Red Wine' (1983) and Bronski Beat's 'Small Town Boy’ (1984), and facilitated one-off videos directed by Nic Roeg and Anton Corbijn; it was active 1983-1986. Midnight Films was run by Michael Hamlyn and represented Julien Temple briefly and was active 1982 -1989. Vivid represented Andy Morahan and was active 1985-1990. AWGO, active 1985-1992, facilitated productions for Greg Masuak and others. These were the leading independent music video production companies in those years. Some record companies in the 1970s, however, had set up in-house production facilities to supply their video content - both long form and short form. One was EMI Records in London's Manchester Square, where music videos for their artists ranging from Pink Floyd to Phil Collins were produced at Picture Music International by the seasoned producers Elizabeth Flowers and Lana Topham. When PMI closed its doors in the 1990s, it deposited many of its analogue video tapes with the BFI National Film Archive.

The ACTT opposed these independent production companies. None of the producers were given ACTT union cards, and almost all of the UK shoots were non-union. At the time, according to Scott Millaney, there was no union model for an independent production company which operated on a very lean core staff and employed all film crew - including often the producers - as freelancers. The Musicians Union also opposed music video productions, because it had not reached a satisfactory royalties arrangement for music video broadcasting with the British Phonograph Industry (BPI). And the $\mathrm{BBC}$ opposed music video because it saw itself as a production company not a broadcaster of 
pre-made content and certainly not promotional content (that was the domain of ITV and, after 1982, Channel 4). So, the establishment environment in Britain was hugely hostile, and Scott Millaney describes a situation in which the ACTT and MU put even more pressure on the BBC not to screen music videos. The result, according to Millaney is that most of the videos made in Britain weren't shown in Britain but, after 1981, were flown directly to the head offices of MTV in New York to play on MTV. ${ }^{5}$ Estimates are that $70-80$ per cent of the videos shown on MTV in the early years were British. MTV wasn't available in the UK in those years, so the material was rarely seen by British audiences. Producer Mike Wells reflects:

The union was geared in those years to the BBC. A lot of people came out of the BBC. There were a lot of people who had full time jobs, were taken on as fulltime employees and were moved up through a strictly hierarchical system, and their knowledge and experience could be kept tabs on. Music video didn't work that way. Music video was a far more modern fluid way of organising things, just in terms of getting it done. It had to be that way and have that energy because it didn't have funds available to it. That shift really took the ACTT by surprise. Their reaction to it rather than to be inclusive was certainly, in my experience anyway, to keep us at arms' length...there was clearly a disinclination to embrace this new form of filmmaking. ${ }^{6}$

It wasn't until the 1980s, however, that a de jure industry existed in the sense of operating on a transparent set of legal terms, although it would be wrong to describe these terms as 'agreements' for they were not terms mutually agreed by all partners or to the satisfaction of all parties. The intellectual property terms were essentially dictated by the Musicians Union and BPI and amounted to the music industry owning everything, and the film industry owning nothing. By the late 1980s record labels had started to charge licence fees (Banks 1997: 302). This meant that music videos had 
shifted from 'commercials' to 'products'. As reflected in the BPI's 1984 report, music video was an intellectual property that the music industry can and should exploit for posterity (Fisher 1984). The report advised that to make that possible, labels should own all copyrights in the music video and should not relinquish any rights to filmmakers and creatives in the video production domain. So, from 1984, the music industry earned licensing revenue from broadcasters, and sales revenue from VHS tapes, followed later by sales revenue from enhanced CDs, and later DVD collections. Whilst the income from these sales was small in comparison to revenue from record sales, the positioning of music video as product was prescient. Following the economic crash in the music industry caused by digital piracy and Napster, it was advertising revenue from music videos on YouTube and other social media platforms that pulled many record labels out of debt in 2013 (Eastwood 2014, UK Music 2017).

By the early 1990s, the political economy of music video production had shifted significantly. In the first instance this was a result of successive Governments dismantling the power of trade unions since Margaret Thatcher came to power in 1979. Whilst the Employment Acts of 1980 and 1982 placed restrictions on the closed shop, the Employment Act (1990) and section 137(1)(a) of the Trade Union and Labour Relations (Consolidation) Act (1992) effectively made them illegal. The Labour Party had supported closed shops until December 1989, when it abandoned the policy in accordance with European legislation. When BECTU was formed in 1991, the result of a merger between the ACTT and BETA (Broadcasting and Entertainment Trades Alliance), its attitude towards the independent music video production companies was wholly different. Scott Millaney describes a day on which BECTU's new representatives arrived at MGMM's offices on Golden Square offering a range of incentives for MGMM to join the union. Millaney declined. ${ }^{7}$ Some of the 'Wild West' practices continued - partly because of the 'Kick, Bollocks and Scramble' production method (Caston, 2012) - but by the early 1990s the non-union sixteen-hour day deal had become established vernacular, and BECTU had no power to 'black' a production company's work for employing crew on it. 
By this time a number of the first-generation production companies had shut down. Few of the early entrepreneurs had much experience in running small businesses; many experienced too much growth, too fast, too soon; some companies had cash flow problems because the record labels were slow to pay. In 1987, Jon Roseman filed for bankruptcy. MGMM went bankrupt in 1991. According to Millaney, MGMM's collapse was caused by the stock market crash. Patrick McKenna, founder of the Ingenius Group (1995-), was the company accountant for MGMM in the 1980s. Millaney had founded a feature film division within MGMM called Initial to develop scripts for his directors and was looking for investment to expand it. McKenna suggested that Millaney apply for a loan against MGMM’s $£ 8$ million assets which included the property on Golden Square that MGMM owned. Millaney successfully secured a bank loan of $£ 2$ million secured against the building. But when the 1980s boom years gave way to a sharp recession in 1990-1 caused by high-interest rates and an over-valued exchange rate which saw property prices plummet, the bank panicked and called in the loan without any warning and any alternative option for MGMM. For Millaney, what took place in the subsequent 48 hours was indicative firstly of the absence of media investment and banking firms with specialist skills in supporting media companies (which exist in 2018), and secondly, of the poorer supports for businesses facing bankruptcies and cash flow problems in the UK than in the USA. The next day an anonymous caller contacted the receivers, and by 6pm when Millaney tried to enter the building, the locks had been changed. Seventy people lost their jobs, and both individuals and company suppliers were left in debt. ${ }^{8}$ Others were victims of the poor legal and financial infrastructure that existed for film SMEs in those days because 'independent production', didn't exist. The story of MGMM's decline illustrates not only this, but the fact than many of the 'pioneer' production and post-production companies in Soho were able to own their own properties.

Another cause for the shift was the effect of the BPI's decision to direct its members to recoup fifty per cent of the production costs of music videos from the artists' sales. ${ }^{9}$ This move, designed to cap rapidly rising budgets, resulted in budgets falling in the UK. Compounding this was the launch of MTV Europe which introduced demand for a greater number of music videos but of a lower budget 
threshold. ${ }^{10}$ Into this demand mix for more content at a lower cost entered a new generation of production companies. Helen Langridge, having run the music video division of Lee Lacey which launched in the UK in 1986 - with directors including Vaughan and Anthea on its roster - left to set up her own production company, Helen Langridge Associates. One of the most influential companies was Oil Factory which was formed in 1987 by Dave Stewart and Annie Lennox although company operations were taken over by Dave's brother John and Annie's then-boyfriend Billy Poveda. Their first offices were in Crouch End in North London, although they later moved to the Caledonian Road. Between March 1987 and December 2005 Oil Factory represented around 50 directors including Sophie Muller, Jamie Thraves, Dom \& Nic, and Pedro Romhanyi. ${ }^{11}$

In crucial respects music video pioneers modelled their businesses on the commercials industry. Unlike the feature film industry which separates the activities of directors' representation on the one hand and film production on the other (the former delivered by literary agents such as William Morris, ICM, Casarotto Marsh and Curtis Brown, and the latter delivered by production companies such as Working Title or Number 9 Films), the music video industry combined both in a single production company. TV commercials production companies did the same. A young person wanting a career in TV commercials or music video would therefore head to Soho in search of work as a runner in order to get a foot in the door of a reputable production company. She would then hope to sign an exclusive permanent deal for her intellectual and creative services to be 'hired out' to clients and in exchange for agreed fees; all intellectual property rights would be owned by the production company, agency, label or client. This means that production companies in music video and commercials operate somewhat like football teams, poaching, buying and selling directors.

Many companies remained financially dependent on the commercials industry. The reduction in music video budgets at the end of the 1980s and early 1990s, combined with increasing second generation business-acumen amongst the MDs of Soho's independent production scene based on avidly circulated horror stories about the bankruptcies of the 1980s, led the pioneers to set up commercials divisions within their companies. There was a fear that if the company didn't have a 
commercials division either directors would leave to join other companies which did (because director fees from commercials were at least treble those of videos), or the company would hit the wall. Harry Rankin was brought into Limelight to set up a commercials division in 1987 to which Danny Kleinman gravitated. Even Oil Factory for a period of time had a commercials division. MGMM bought in two established producers from commercials to run their division: 'Springhall and Fanthorpe were known to the agencies and were seen as a safe pair of hands because most of us in music videos were seen as a little bit gung-ho. I don't think the commercials world - the more traditional world - knew how to deal with all of us music video people. And at GLO there was a guy called John Spary,' explains Mike Wells. ${ }^{12}$

Adam Dunlop, producer, commissioner and editor, believes music video never succeeded in becoming more than 'the poorer little brother of commercials' (Caston 2017: 109). One of the things that helped the new commercials' producers to establish a secure place in the legal infrastructure of the ACTT back in the 1950s was that immediately ITV launched, they set up an effective professional trade association. The Advertising Producers' Association (APA) was established in 1955, initially as the Advertising Film Producers' Association, to articulate and protect the interests of TV commercials producers, and in the 1960s was able to negotiate standard terms of trade between producers, the IPA (Institute of Practitioners in Advertising) (agencies) and ISBA (Incorporated Society of British Advertisers) (clients) for the production of commercials. It remains an influential organisation in Soho today representing 245 production companies, animation, VFX, sound design, music and editing. The music video industry had not had that advantage, perhaps not only because of the pioneer skillset of the first generation of producers, but the absence of any collective identity. Helen Langridge believed that in the early days of the Music Video Producers Association (MVPA), 'it was awful ... There was so much freedom and not a lot of understanding ... people were very much out for their own, what worked for them'. ${ }^{13}$ The first attempt to set up an MVPA in Britain failed, as I have documented elsewhere, and failed again in the 1990s (Caston et al 2000). Today, industry support and representation are still provided by the parent company, the APA. One of the 
damaging economic consequences of the failure of the pioneers to act collectively to defend their interests was that they lost control of their intellectual property. Compensation for the use of a director's work is negotiated and collected by Directors UK, the Collective Management Organisation (CMO) which negotiates with broadcasters such as the BBC, ITV, Channel 4, Channel 5, Sky, and S4C. PACT represents the IP interests of film and television producers. Music video directors and producers benefit from the protection of neither.

The 2000s saw a new generation of production companies enter the market: Rogue, Stink, Pulse, Riff Raff, Somesuch, and Outsider. The 2010s saw a further set: Kode, Knucklehead, OB, Caviar, My Accomplice, Iconoclast, Prettybird. The only major companies from the 1980s and 1990s to survive were Ridley Scott Associates, Helen Langridge Associates, and Academy. Limelight shut its doors in 1990. Propaganda Films closed as a result of the Seagram buyout of Polygram documented by Kuhn (2002). In 2005, Oil Factory ceased production, although producers like Toby Tremlett continued to represent several directors through offshoot Factory Films. Full analysis of the changes driving these generational economic shifts is beyond the scope of this article but would make a valuable contribution to the literature on SME finance and sustainability in film (e.g. Northern Alliance 2014), and to work on the Soho clusters (e.g. BOP Consulting), and cluster lifecycles (e.g. Menzel and Fornahl 2010).

\section{The R\&D Function of Music Video}

There is no doubt that music video functioned as an R\&D sector in cinematography, production, video-tape and colour-grading for the British screen production industry as a whole. R\&D is where the much desired 'innovations' of creative economies occur. In recent years there has been interest in mapping innovation within the Soho cluster of film and television companies (Pratt and Gornostaeva 2009; Chapain and Stachowiak 2017), so understanding how R\&D sectors work in the screen industries is crucial in building supportive training, taxation and policy environments. Creative Skillset has been tasked with mapping career pathways and identifying future skills 
requirements for the screen industries, but with the odd exception (e.g. Ogborn 2000), there are still few publications on career pathways across and between the value chains that capture the role of music video as a talent development nursery for aspiring filmmakers to learn their craft.

Academy Award nominee and BAFTA-winning director of photography John Mathieson began his career on a Siouxsie and the Banshees music video directed by Peter Scammel and worked on a significant number of landmark British music videos including Massive Attack's 'Unfinished Sympathy’ (Baillie Walsh, 1991), UNKLE’s 'Rabbit in your Headlights' (Jonathan Glazer, 1998), and Kylie Minogue's 'Can't Get you Out of my Head' (Dawn Shadforth, 2001). It was at Black Dog Films, the music video division of RSA, that he came to the attention first of Jake Scott (for whom he lit the feature film Plunkett and Macleane (1999) and several videos including Madonna's 'American Pie' (2000)), and subsequently Ridley Scott. After witnessing three suicides in the music video industry, the last of which was Kurt Cobain, Mathieson decided that he had to move into feature films as had always been his ambition when he first started to shoot movies with his father's Super 8 camera at home:

Make a film. Whatever you do 'Make the film. Make the film'. I was like...'Make it, make it. What's the matter, we just got to do stuff. Get noticed.' But it's like you pull yourself off. You bang your head against the wall, before you get yourself up on that plateau. Just get a leg over the wall. You fall down the other side in the mud, you're not going to climb up another sort of like an Aztec pyramid to get to the other, to get to the top before anyone notices you. But I got a film in France, called 'Pigalle'*. About the goings on in Pigalle, their sort of Soho red-light area, and it was about scallywags and gangsters running about. Guys turning tricks and petty thieves. And I thought, oh I'll go and do that, because at least it'll be all in French. So, if it's shit, at least it's in French ... If you're a music video or commercials director of photography that's all they think you are. You've got to fight and kick your way in ... You were looked down on... you weren't respected. ${ }^{14}$ 
Mathieson is not the only British cinematographer to have begun his career in music videos. Seamus McGarvey ${ }^{15}$ photographed and directed over 100 music videos for artists including U2, The Rolling Stones, PJ Harvey, Robbie Williams, Sir Paul McCartney, Dusty Springfield and Coldplay. Nic Knowland ${ }^{16}$ worked on music videos for Nigel Dick, Russell Mulcahy and Liam \& Grant. Dan Landin ${ }^{17}$ worked as the cinematographer on videos for The Cure, Bjork, Mansun, The Verve, David Bowie, Massive Attack, Robbie Williams, Oasis, and Madonna. Acclaimed cinematographer Robbie Ryan ${ }^{18}$ also began his career on music videos for Hurts, MIA, Ellie Goulding, Dizzee Rascal, Kasabian, Basement Jaxx, Plan B, Sam Smith, Coldplay, and The Script. Dick Pope ${ }^{19}$ worked in music videos, as did Martin Coppen and Rob Hardy. Roger Deakins began his career lighting music videos for Nigel Dick, Jeff Baynes with Russell Mulcahy, Mike Southon with Andy Morahan, and John Melcalfe with Don Letts.

The fact that many of Britain's feature film directors began their careers in music video is more widely known; for example: Julien Temple ${ }^{20}$ Andy Morahan, ${ }^{21}$ Jamie Thraves, ${ }^{22}$ Jonathan Glazer, ${ }^{23}$ Steve Barron, ${ }^{24}$ David Slade, ${ }^{25}$ Daniel Wolfe,${ }^{26}$ Max and Dania. ${ }^{27}$ These directors did not only learn their trade directing music videos: they were innovative in creating some of the UK's landmark music videos. On the other side of the Atlantic, directors such as Spike Jonze, Michel Gondry, and David Fincher produced equally outstanding and critically acclaimed videos for artists such as Fat Boy Slim, Bjork, Daft Punk, The Chemical Brothers and Madonna before their careers in feature film took off; significantly this latter group were all represented by Propaganda Films.

The use of music video as a route to a career in feature films was established in the 1980s. By the early 1990s most companies had either set up satellite offices in Los Angeles to try to 'break' Hollywood for their directors or had put deals in place with American companies for representation. RSA, Limelight, Oil Factory, and Propaganda all set up offices in Los Angeles. Many directors refused to shoot on videotape, resolute that music video could and should be a cinematic art form and a calling card for representation with a Hollywood film agent. They shot on $35 \mathrm{~mm}$ or if the 
budget couldn't stretch, $16 \mathrm{~mm}$. In order to achieve a widescreen aspect radios of 16:9 when broadcast on the academy frame of $4: 3$ on domestic television sets, directors cropped the top and bottom of their frame with black gaffer tape. Examples of this include Steve Barron's video for The Human League's ‘Don’t You Want Me' (1981) and Russell Mulcahy's video for Ultravox's 'Vienna' (1980).

Music video also nurtured today's leading British film producers, like Working Title's Tim Bevan. At Aldabra the roster of directors included Nic Roeg, Derek Jarman, Anton Corbjin and John Scarlett-Davis. Bernard Rose describes Tim's office as no larger than a cupboard in a cutting room in Dead End Street in Soho. ${ }^{28}$ From Aldabra, Bevan and Radclyffe created Working Title, later joined by Eric Fellner who had been working down the road at MGMM. Millaney reports that Fellner was a runner with Simon Fields when they first met. When Mulcahy and Mallet left Roseman's production company to join MGMM, Millaney needed some new producers to support the expanded roster of directors. He offered Fellner a contract. Fellner refused, and the pair fell out. Fellner left and went to Africa for a year. Later, Millaney found Fellner in a pub one day and said 'please start a film division; find some screenplays.' Fellner launched Initial from a desk in the MGMM building on Golden Square funded entirely by MGMM money. He found the script for Sid and Nancy (Alex Cox, 1986). Cox came in with the script and said he couldn't clear the music. Initial went on to make seven movies including Pascali's Island (1988), Hidden Agenda (1990), and Liebstruam (1991), before MGMM went bankrupt. ${ }^{29}$ It was from this that Initial TV was born. Malcolm Gerrie explains how he moved from being the producer of The Tube (C4: 1982-1987) to running the TV division. In 1988, 'I was asked by Eric Fellner at Initial Pictures to come and set up their TV production division. But in 1991 our parent company, MGMM, went belly-up. It was a shock at first, but Eric then suggested we buy Initial, so we went to the lawyers and three days later we owned it - which was a brilliant feeling' (Hughes 1998: NP). As well as owning Initial, MGMM co-founded Visions on Dean Street and launched and co-owned Double Vision for tape duplication.

Besides providing a launch-pad for feature film production, music video producers were also, from the mid-1970s onwards, pioneers in the new videotape technology. This meant they incurred 
the wrath of the ACTT and BBC. At the time, video tape recording for television was made on twoinch tape using a 'quad' scanning system which exhibited high stability and reproduction quality. The tape formats music video directors were experimenting with weren't yet regarded as of 'broadcast' quality: they had to be recoded and resynchronized to be broadcast with adequate reception on television; these were the $1 / 2$ inch, $3 / 4$ inch and 1 inch tapes which used a helical scanning system (Marshall 1979: 111). ${ }^{30}$ There was a union ban on the broadcast of helical scan material in the late 1970s. The ACTT opposed these not only for reasons of technical standards, but because they reduced the number of people needed for location camera crews and post-production teams and feared skills changes would mean redundancies. Marshall reports that the ACTT harboured internal conflicts between its film and electronic technician members and initiated discussions with video engineers, vision mixers and film editors about retraining film editors made redundant by the increased use of video tape (Marshall 1979: 112).

Whilst video directors such as Mulcahy, Barron and Temple wanted to shoot on film, the impetus to work on video came from two sources in music video: the video directors from an artist filmmakers' production culture, and the editors. Video director Richard Heslop was part of a movement keen to explore 'synesthetic abstraction' - a term used by Marshall to denote 'the electronic generation of abstract imagery using video synthesizers and image colourizers' (ibid). Fowler (2017) has explored this in his analysis of the video artists in the early 1980s - in particular Cabaret Voltaire's label Double Vision which released Heslop's 'Seven Songs' (2017: 65). Other directors who were experimenting with video at this time included Jayson Perry, Isaac Julien, Cerith Wyn Evans, and Derek Jarman (Fowler 2017: 67-70).

Molinare, today a leading British post-production house, was founded in 1973 and was an early adopter of the new technology. In 1976 the founder Stefan Sargent purchased three Ampex one-inch helical tape recorders and built the first one-inch edit suite outside the USA. But the ACTT blacklisted the company for this which meant that UK broadcasters were instructed by the ACTT and their management not to playout any video tape from Molinare. After a meeting with the general 
secretary of the ACTT Alan Sapper, Sargent's legal team took the ACTT to court over 'restrictive trade practices'. In court, the ACTT reached a settlement that allowed Molinare to trade using the 1 inch technology. ${ }^{31}$ This example shows that rather than being hailed as the inventors of new technologies that would invigorate British production, the 'pioneers' in the post-production houses were thwarted and devalued. Not only did the ACTT try to block their innovations, but ACTT members degraded their new work processes. Tony Kearns reports that David Yardley was told by a film editor that if he was cutting on video tape rather than celluloid he was 'just an engineer'. Yardley was hurt. Kearns recalls, 'There was a snobbery about video at the time. Actually interestingly enough, until the ' 90 s there was quite a degree of snobbery in other areas about music videos. They were dismissed as being like messing around ... not proper filmmaking... [they] were really looked down on'. (Caston 2017: 108).

Perhaps the single most important legacy of music videos is the invention of colour grading, now heralded as a major creative component of the British film and television industries. It wasn't until the late 1990s that feature film producers began to experiment seriously with colour grading as part of the post production workflow (see Higgins 2003). But in music video colour grading as a creative craft was already firmly established by the late 1980s; and within the decade there were highly paid colourist 'superstars': Aiden Farrell at Molinaire (later of The Farm, co-sponsored by WPP), Aiden Seerey at Rushes (who had begun his career at SVC), Tom Russell at VTR (who later joined Lip Sync); Jean-Clement Soret (later Global Creative Director of Colour Grading at MPC).

In the early years, telecine was simply the term for an operational process by which celluloid was scanned to videotape so that it could be broadcast on TV. It wasn't treated with respect. The early telecine equipment was largely developed by the BBC. But during the 1970s and 1980s a number of independent post-production companies in Soho started to develop the technology further to create artistic opportunities, amongst them VTR, Video Tape Recording, founded in the 1960s and Rushes, founded in 1977. The first generation of creative colourists developed the technology. The scanning equipment used in these companies was URSA - in 1993 the URSA was replaced by Ursa 
Gold. There were two main alternative sets of equipment used to treat the scanned material: the Resolve system offered by De Vinci based in Florida (founded in 1984), or the Pogle system offered by Pandora which was a British company, launched to compete with De Vinci in 1985 as Digi-Grade International Ltd. In 1987, the company changed its name to Pandora International. Pandora made Pogle which was a system that could control both a telecine scanner and a DCP. DCP or Digital Color Processor was a standard-definition digital video processor controlled by a Pogle. DCP was one of the first commercially available systems which was built entirely with digital circuitry using programmable logic. Until this time most colour manipulation (including the circuity within Telecine machines) was analogue. With the DCP, primary and secondary colour processing could be done outside the telecine and so input could be from film or video tape. The possibilities thereafter were huge.

The video for George Michael's 'Faith’ (1987) directly illustrates this. It was colour-graded at SVC Television, one of the leading London post-production houses which had been founded in 1973 (and subsequently dissolved in 2012). The director, Andy Morahan, cannot remember who graded it but thinks Tom Russell was one of the team:

And because we had been working closely with the post-production companies we were the first in on all that stuff. I mean 'Faith' looks a bit naive with all the colourisation and all that but you know in those days it was a Pandora's Box: 'Oh Fuck we can do this! Oh Fuck! We can do that'. And that's precisely because we were working quite closely with post-production companies ahead of the commercials people, and all that kind of stuff, who were just simply using them as a way of mastering stuff as a way of going online for broadcast. [At VTR], Seamus O'Kane was a big part of that. He was the artistic side of Pandora. He was an operator but he told Pandora what he wanted: 'I want to be able to change skin tones'. ${ }^{32}$

Aidan Farrell used to treat the scanned video material with Vaseline, stockings, and coloured glass, and new software would be developed by Pandora to mimic these effects. ${ }^{33}$ 
Colour grading is a story of British creatives working hand in hand with the British computing and software industry to develop world class film FX, just one of many case studies in which the VFX, post-production, and audio houses in Soho have had a huge impact on the world screen industries. Representing the establishment's recognition of the 'art' and 'industry' of colour grading was the award by BAFTA in their 2012 Television Craft Awards of the Industry-renowned colourist, Aidan Farrell, received the Academy's Special Award at the British Academy Television Craft Awards on Sunday 13 May.

The impact of these initiatives on the commercials world was as great if not greater than on the feature world. As soon as MTV was available on cable and satellite in the UK, creatives in London's advertising agencies would have the channel running all day in their offices. MTV would also run 24/7 in the offices of the commercial directors at the production companies. So when videos were broadcast that pioneered new lenses the cinematographers had experimented with, the fashionable new blue/grey grade of Tareq Kubaisi at VTR in the 1990s, or the talents of a new up and coming director such as Chris Cunningham, the agency creatives would want to hire those suppliers and crew. Music video was without question, the 'early adopter' of new production practices and new technologies in the screen industries. It was also, in the language of the Boston Matrix, the loss leader. But it was a vital part of the ecology of screen production at those companies which operated 'diverse' portfolios such as Ridley Scott Associates, with television, film, music video and commercials divisions. And it is significant that those companies which established footholds successfully in all of those sectors, have remained British-owned, and have remained in profitable business where others have gone bust or been sold to the USA. Ridley Scott Associates celebrated its fiftieth anniversary in 2018.

\section{The Cultural Hierarchy of Film Production}

One potential explanation for the cultural hierarchy of film production is that music video emerged as a service industry rather than a producing industry. In a service industry, the production company 
functions as a facilities house and does not own any of the intellectual property in the work. In a producing industry, the company has a claim to copyright (see Figure 3 below).

\section{INSERT Figure 3}

The diagram requires a grasp of the difference between an industry's legal, applied and concrete definition of the producer as stipulated in the contracts, and an industry's actual 'producer', i.e. the individual or company who originates and secures finance for the moving image work. By precedent, and as a result of the political machinations of the various trade bodies and corporations involved, the production companies in the hidden screen industries lost control of their rights and fell into a set of institutional arrangements whereby the funders and commissioners of their films were legally defined as producers and thereby legally retained the intellectual property. In effect the producers of the hidden screen industries are suppliers operating as a service industry.

Although much has been written generally on the impact of copyright extension, digital distribution and the creative commons movement in the creative industries, relatively little has been written on the copyright arrangements within the different screen industries in England and Wales in relation to the 'defined term' of the producer, save for Kamina's survey of film copyright in the European Union (2016), and Grantham's analysis of the differences between the French and North American copyright regimes (2000). In the law of England and Wales, the person who creates a work in which copyright subsists is the first owner of such a copyright (unless the author is an employee). Where the copyright is a film, the author is the producer and principal director jointly (if they are separate people). The 1988 Copyright Designs and Patents Act defines the 'producer' but not the principal director. It defines the producer as 'the person by whom the arrangements necessary for the making of the .... Film are undertaken' (1988: section 178). In most cases the producer is defined as a production company or broadcaster. 
In the music video industry, record labels almost invariably define themselves as 'the producer' in production arrangements. They do not permit the production company to be identified as the 'production company'. This means that they hold the default copyright. Historically production companies did not challenge this, nor did they have a strong professional association to do so. When a freelance director took on a music video s/he would sign a contract containing a clause in which all of their rights are assigned to the record company. This would enable the record company to own all the copyright in the work which means they can commercially exploit the music video. The label would, furthermore, require the director to waive moral rights including the 'right of attribution' and would present the 'artist' as the 'author' in marketing and credits information such as the titles for MTV.

However, industry commentators such as Angus Finney have long argued that in Britain many film producers aren't able to retain their IP and that this is the major obstacle to a sustainable production film industry in the UK (see Bintliff 2011 and Macnab 2018). In addition, the increasing number of British television production companies owned by the United States was called out for attention by David Abrahams, CEO at Channel 4, at the Edinburgh International Television Festival in 2014, and subsequently reported across the media (see Plunkett 2014). ${ }^{34}$ In its annual survey, the 'Production 100', Televisual regularly reports on the trend for overseas ownership of the super indies. Additionally, the flow of IP is not always upwards, and the funding arrangements for features with Netflix and Amazon increasingly see IP not retained by British producers (Garrahan 2017). ${ }^{35}$

Nevertheless, this distinction is crucial. In terms of their origins, the hidden screen industries - if we define them as industrial films - were intrinsically created with the client as the producer / owner / author from the very start, by contrast to which feature films and artists' films and videos were industrial innovations in that a supposedly 'free' artist or set of 'artists' were claimed to be the producers / owners / authors. With these supposedly 'free' artists as authors, these types of films were, it was claimed, legitimate works of culture, worthy of being placed at the top of the hierarchy of screen arts in a way that industrial film was not. The irony (or not) is that those industries at the 
base of the cultural hierarchy have made, in proportion, perhaps the greatest economic contribution relative to their capacity. Figure 4 from a 2004 report on British post-production commissioned by the UK Film Council illustrates the point.

\section{INSERT Figure 4 (Source: Post-production in the UK, UK Film Council 2004)}

The problem here is the assumption that producers and owners and authors are the same. Just because the producer and copyright owner of an industrial film is the industrial client, that does not mean either that the 'artistic creators' of the film are the same client or that they do not have 'artistic freedom'. In the 1980s and 90s music videos were the perfect example of the contrary - the producer was client, but the director had absolute creative freedom. As Nick Egan told the New York Times, music video was at that point 'the last bastion' of 'the auteur' (Foege 1995). So, whilst the legal distinction about producers as owners of copyright might explain how the cultural hierarchy emerged according to which music video, qua industrial film, was lumped at the bottom, it is not a distinction that withstands any evidence-based analysis. Historians and curators of TV commercials, fashion films and other types of industrial film might argue the same point for those respective sectors.

The old saying is that the pioneers take the arrows, and the settlers the land. Most companies that made music videos went bankrupt, and those individuals who went on to successful careers in the screen industries did so in TV or feature films. The high-end TV and feature film sectors have made money from cinematographers, producers, video and digital technologies pioneered in music video. But it would be wrong to say that the British TV and film companies took the land. The Americans have taken the land.

\section{Conclusion}


The objective of this research project was to produce a history of the independent production sector in music video. A full account of that history will be published in a subsequent book for Edinburgh University Press (forthcoming 2020). This article serves to identify the core paradigmatic change needed in film and television studies, building on recent work by colleagues which challenges the disciplinary boundaries. It is necessary to think beyond the ideologies arising from the political economies we study, in order to consider social phenomena in historical context. How we categorise music video has consequences for public policy: it impacts copyright legislation, education and training, taxation, and cultural heritage. It affects our conservation policies and cultural heritage strategy. It is hoped that this article contributes to moving the discussion forwards. Something that has not been addressed here is that hierarchies of cultural value differ for new generations. An issue for Government is whether policies affecting education, training and cultural heritage should be determined by the retiring generations, or the generations on the rise. And where do the producers of user-generated content sit in a history of independent screen production? If 'the establishment' failed to spot the crucial economic benefits of the pioneer music video producers and failed to put in place the right economic and legal protections to ensure a long-term income stream for their work, are they also failing to protect the user-generated producers of today? Our guiding policy should be that the pioneers are protected.

\footnotetext{
${ }^{1}$ BFI curator Patrick Russell (2011) has written an eloquent history of what is often termed 'sponsored film', and it is also the focus of Hediger and Vonderau's book Films That Work (2008).

${ }^{2}$ Ray Davies, email interviewed with Miriam Newman, 1 May 2015.

${ }^{3}$ Peter Whitehead, email interview with the author, 6 November 2015.

${ }^{4}$ John Crome, interview with the author, 9 May 2017.

${ }^{5}$ Scott Millaney, interview with the author, 12 April 2018.

${ }^{6}$ Mike Wells, interview with the author, 7 March 2018.

${ }^{7}$ Scott Millaney, interview with the author, 12 April 2018.

${ }^{8}$ Scott Millaney and Brian Grant, interview with the author, 12 April 2018.

${ }^{9}$ Rob Dickens, interview with the author, 16 July 2015.

${ }^{10}$ Andy Morahan, interview with the author, 11 May 2016.

${ }^{11}$ John Stewart, interview with the author, 19 March 2015.

${ }^{12}$ Mike Wells, interview with the author, 7 March 2018.
} 
${ }^{13}$ Helen Langridge, interview with the author, 13 November 2016.

${ }^{14}$ John Mathieson, interview with the author, 8 January 2018.

${ }^{15}$ Atonement (2007), Anna Karina (2012).

${ }^{16}$ The Great Rock ' $n$ ' Roll Swindle (1980), Institute Benjamenta (1995), Berberian Sound Studio (2012), The Duke of Burgundy (2015).

${ }^{17}$ Under the Skin (2013), The Yellow Birds (2017).

${ }^{18}$ Red Road (2006), Brick Lane (2007), Fish Tank (2009), I am Slave (2010), Wuthering Heights (2011), Ginger and Rosa (2012), Philomena (2013), Jimmy's Hall (2014), American Honey (2016), I, Daniel Blake (2016).

${ }^{19}$ Secrets and Lies (1996), The Illusionist (2006), Mr Turner (2014).

${ }^{20}$ The Great Rock 'n' Roll Swindle (1980), Absolute Beginners (1986), Earth Girls are Easy (1998), Vigo A Passion for Life (1998), The Filth and the Fury (2000), London The Modern Babylon (2012).

${ }^{21}$ Highlander III (1994)

${ }^{22}$ The Low Down (2000), The Cry of The Owl (2009), Treacle Jnr (2010), Pick Ups (2017).

${ }^{23}$ Sexy Beast (2000), Birth (2004), Under the Skin (2013).

${ }^{24}$ Electric Dreams (1984), Teenage Mutant Ninja Turtles (1990).

${ }^{25}$ Hard Candy (2005), The Twilight Saga: Eclipse (2010).

${ }^{26}$ Catch Me Daddy (2014).

27 Streetdance (2010).

${ }^{28}$ Bernard Rose, interview with the author, 26 October 2016.

${ }^{29}$ Scott Millaney, interview with the author, 12 April 2018.

30 These were the technologies being developed by the independent production companies for news - "Electronic News Gathering".

${ }^{31} \mathrm{https}: / /$ stefansargent.com/2013/08/21/the-shiny-black-door/

${ }^{32}$ Tareq Kubaisi, interview with the author, 24 January 2018.

${ }^{33}$ Aidan Farrell, interview with the author, 15 March 2018.

\section{References}

Bakhshi, H., Hargreaves, I. and Mateos-Garcia, J. (2013), A manifesto for the creative economy, https://media.nesta.org.uk/documents/a-manifesto-for-the-creative-economy-april13.pdf (accessed 10 December 2015).

Bakhshi, H., Davies, J., Freeman, A. and Higgs, P. (2015), The geography of the UK's creative and high-tech economies, https://media.nesta.org.uk/documents/geography_uks_creative_hightech_economieswv20151.pdf (accessed 10 December 2015).

Banks, J. (1997), 'Video in the Machine: The Incorporation of Music Video into the Recording Industry', Popular Music, 16: 3, pp. 293-309.

Bazalgette, P. (2017), Independent review of the creative industries, Department for Digital, Culture, Media and Sport, UK Government, https://assets.publishing.service.gov.uk/government/uploads/system/uploads/attachment_dat a/file/649980/Independent_Review_of_the_Creative_Industries.pdf (accessed 15 May 2018).

Bintliff, E. (2011), 'What's Holding the UK Film Industry Back?', Financial Times, January 14, https://www.ft.com/content/3eea920c-1f55-11e0-8c1c-00144feab49a (accessed 15 May 2018). 
BOP Consulting, Soho: The World's Creative Hub, http://www.thecreativeindustries.co.uk (accessed 13 May 2018).

Bourdieu, P. and Passeron, J.-C. (1990), Reproduction in Education, Society and Culture, London: Sage Publications.

Caldwell, J. T. (2008), Production culture: industrial reflexivity and critical practice in film and television, Durham, N.C.: Duke University Press.

Cambridge Econometrics (2005), 'Economic Impact of the UK Screen Industries - a report submitted to the UK Film Council', https://www.bfi.org.uk/sites/bfi.org.uk/files/downloads/economic-impact-of-the-uk-screenindustries-2005-05-13.pdf (accessed 14 December 2014).

Carey, H., Crowley, L., Dudley, C., Sheldon, H. and Giles, L. (2017), 'A Skills Audit of the UK Film and Screen Industries: A Report for the British Film Institute', http://www.theworkfoundation.com/wp-content/uploads/2016/10/420_A-Skills-Audit-ofthe-UK-Film-and-Screen-Industries.pdf (accessed 15 May 2018).

Caston, E. (2012), “Kick, bollocks and scramble": An examination of power and creative decisionmaking in the production process during the golden era of British music videos 19952001', Journal of British Cinema and Television, 9: 1, pp. 96-110.

Caston, E. (2017), 'The First Cut is the Deepest': Excerpts from a Focus Group on Editing Music Videos, with Explanatory Historical and Theoretical Notes', Music, Sound and the Moving Image, 11: 1, pp. 99-118.

Caston, E. and Smith, J. (2017), 'Fifty years of British music video', Music, Sound and the Moving Image, 11: 1, pp. 1-9.

Caston, E., Parti, N., Walker, N. and Sutton, C. (2000), 'Report on the Music Video Industry in 1998 and 1999', Promo, May, pp. 6-7.

Chapain, C. and Stachowiak, K. (2017), 'Innovation Dynamic in the Film Industry: The Case of the Soho Cluster in London', in C. Chapain and T. Stryjakiewicz (eds), Creative Industries in Europe: Drivers of new sectoral and spatial dynamics, New York: Springer, pp. 65-94.

Dickinson, K. (2003), 'Pop, speed, teenagers and the "MTV aesthetic"', in K. Dickinson (ed.), Movie Music: The Film Reader, London: Routledge, pp. 143-51.

Donnelly, K. J. (2007), 'Experimental music video and television', in L. Mulvey and J. Sexton (eds), Experimental British Television, Manchester: Manchester University Press, pp. 166179.

Ellis, J. (2011), 'Essay on Interstitials', in P. Grainge (ed.), Ephemeral Media: Transitory Screen Culture from Television to YouTube, London: BFI / Palgrave Macmillan, pp. 56-69.

Finney, A. (1996), The Egos Have Landed: The Rise and Fall of Palace Pictures, London: Heinemann. 
Fisher, C. (1984), Music Video: A Specially Commissioned Report, Consultant Editor: Michael Kuhn, London: Oyez Longman Intelligence Reports.

Fletcher, J. (1983), 'Natural Break', in Association of Cinematograph Television and Allied Technicians, Action! Fifty Years in the Life of a Union, London: Pear Publications, pp.115-117.

Foege, A. (1995), 'Out of Crass Commerce Arises the New Auteur', The New York Times, August 27, p. 26.

Fowler, W. (2017), 'The Occult Roots of MTV: British Music Video and Underground FilmMaking in the 1980s', Music, Sound, and the Moving Image, 11: 1, pp. 63-77.

Garrahan, M. (2017), 'Disrupting Hollywood: Amazon Goes to the Oscars', Financial Times, February 17, https://www.ft.com/content/d4784afe-f432-11e6-95ee-f14e55513608 (accessed 18 May 2018).

Garrett, J. (1986), 'Commercial Production', in B. Henry (ed.), British Television Advertising: The First 30 Years, London: Century Benham, pp. 383-402.

Grainge, P. and Johnson, C. (2015), Promotional Screen Industries (London: Routledge).

Grantham, B. (2000), Some Big Bourgeois Brothel, Luton: University of Luton Press

Hediger, V. and Vonderau, P. (eds.) (2014), Films that Work. Industrial Film and the Productivity of Media: Studies in the Visual Culture of the Industrial Film (Film Culture in Transition), Amsterdam: Amsterdam University Press.

Higgins, S. (2003), 'A New Colour Consciousness: Colour in the Digital Age', Convergence: The International Journal of Research into New Media Technologies, 9: 4, pp. 60-76.

Hill, J. (2004), 'UK Film Policy, Cultural Capital and Social Exclusion', Cultural Trends, 13: 2, pp. 29-39.

Hill, J. and McLoone, M. (eds.) (1996), Big Picture Small Screen: The Relations Between Film and Television, Luton: University of Luton Press/John Libbey Media.

Hughes, S. (1998), 'CV: Malcolm Gerrie Managing Director of Initial', The Independent, 1 June.

Kamina, P. (2016), Film copyright in the European Union (Vol. 33), Cambridge: Cambridge University Press.

Kuhn, M. (2002), One Hundred Films and a Funeral: The Life and Death of Polygram Films, London: Thorogood.

Macnab, G. (2018), 'Britain's film renaissance: made in UK, owned in USA?', Financial Times, April 30, https://www.ft.com/content/90908690-373d-11e8-b161-65936015ebc3 (accessed 20 May 2018).

Marks, C. and Tannenbaum, R. (2012), I Want My MTV: The Uncensored Story of the Music Video Revolution, New York: Plume Books.

Marshall, S. (1979), 'Video: Technology and Practice', Screen, 20: 1, pp. 109-119. 
Menzel, M.-P. and Fornahl, D. (2010), 'Cluster life cycles-dimensions and rationales of cluster evolution', Industrial and Corporate Change, 19: 1, pp. 205-238.

Northern Alliance (2014), The Corporate Finance of SMEs in the UK Film Industry: A Report for the British Film Institute, https://www.bfi.org.uk/sites/bfi.org.uk/files/downloads/uk-filmcouncil-analysis-of-the-corporate-finance-of-smes-in-the-uk-film-industry.pdf (accessed 15 May 2018)

Olsberg with Nordacity (2015), Economic Contribution of the of the UK's Film, High-End TV, Video Game, and Animation Programming Sectors, http://www.bfi.org.uk/educationresearch/film-industry-statistics-reports/reports/uk-film-economy/economic-contributionuks-film-sectors (accessed 20 May 2018)

Ogborn, K. (2000), 'Pathways into the industry', in R. Murphy (ed.), British Cinema of the 90s, London: British Film Institute, pp. 60-67.

Oxera (2017), Impacts of leaving the EU on the UK Screen Sector: Prepared for the Screen Sector Task Force, https://www.bfi.org.uk/sites/bfi.org.uk/files/downloads/bfi-impact-leaving-euuk-screen-sector-2017-v1.pdf (accessed 20 May 2018).

Percival, N. and Hesmondhalgh, D. (2014), 'Unpaid work in the UK television and film industries: Resistance and changing attitudes', European Journal of Communication, 29: 2, pp. 188203.

Plunkett, J. (2014) 'British TV industry at risk from US tech and media giants, says Channel 4 chief', The Guardian, 21 August, https://www.theguardian.com/media/2014/aug/21/britishtv-industry-risk-us-tech-media-channel-4-david-abraham (accessed 15 May 2018).

Powell, H. (2013), Promotional Culture and Convergence: Markets, Methods, Media (London: Routledge.

Pratt, A. C., and Gornostaeva, G. (2009), 'The governance of innovation in the film and television industry: a case study of London, UK', in A. C. Pratt and P. Jeffcutt (eds), Creativity, Innovation and the Cultural Economy, London: Routledge, pp. 119-136.

Richardson, J. (2011), An Eye for Music: Popular Music and the Audiovisual Surreal, Oxford: Oxford University Press.

Russell, P. (2011), 'From Acorns to Oak: Industrial and Corporate Films in Britain', Business Archives, https://www.academia.edu/16506574/From_Acorn_to_Oak_Industrial_and_Corporate_Fil ms_in_Britain_Business_Archives_2011_(accessed 20 May 2018).

UK Music (2017), Measuring Music: 2017 Report, https://www.ukmusic.org/research/measuring-music-2017/ (accessed 18 May 2018).

Vernallis, C. (2008), 'Music video, songs, sound: Experience, technique and emotion in Eternal Sunshine of the Spotless Mind', Screen, 49: 3, pp. 277-297. 
UK Government Legislation (1988), Copyright Designs and Patents Act, Section 178, https://www.legislation.gov.uk/ukpga/1988/48/section/178 (accessed 20 May 2018).

Work Foundation (2007), 'Staying ahead: the economic performance of the UK's creative industries', Department for Culture, Media and Sport, UK Government, https://www.an.co.uk/research/staying-ahead-the-economic-performance-of-the-uks-creative-industries-3/ (accessed 18 May 2018). 